\title{
Health Promotion In The Work Context, Beyond A Healthy Organizational Model
}

La promoción de la salud en el contexto laboral, más allá de un modelo organizacional saludable

Promoção da saúde no contexto do local de trabalho, além de um modelo organizacional saudável

\section{Mónica Mahecha Guzmán ${ }^{1}$ Evelin Lizeth Silva Urrea ${ }^{2}$ Fabiola Sáenz Blanco ${ }^{3}$}

Received: January $20^{\text {th }}, 2020$

Accepted: April $02^{\text {th }}, 2020$

Available: May $4^{\text {th }}, 2020$

How to cite this article: M. Mahecha Guzmán, E. L. Silva Urrea, F. Saénz Blanco, "Health Promotion in The Work Context, Beyond a Healthy Organizational Model," Revista Ingeniería Solidaria, vol. 16, no. 2, 2020. doi: https://doi.org/10.16925/2357-6014.2020.02.02

Artículo de investigación. https://doi.org/10.16925/2357-6014.2020.02.02

1 Student. Faculty of Engineering. Industrial Engineering. Universidad Distrital Francisco José de Caldas. Colombia.

E-mail: mmahechag@correo.udistrital.edu.co

ORCID: https://orcid.org/0000-0002-0159-2808

2 Faculty of Engineering. Industrial Engineering. Universidad Distrital Francisco José de Caldas. Colombia.

E-mail: elsilvau@correo.udistrital.edu.co

ORCID: https://orcid.org/0000-0002-7913-7688

3 Faculty of Engineering. Industrial Engineering. Universidad Distrital Francisco José de Caldas. Colombia.

E-mail: fsaenz@udistrital.edu.com

ORCID: https://orcid.org/0000-0003-0040-1296 


\section{Abstract}

Introduction: This article is a product of the research "Health and Psychosocial Well-Being in Organizations: Effectiveness of positive interventions to improve working life from Positive Psychology" carried out during 2016 and 2018 at Universitat Jaume I in Spain.

Problem: The changing conditions of the ecosystems, in which the organizations are immersed, correspond to the growing relationships between the different actors within and outside the organizational context. This constitutes a complex system, difficult to understand in the business context, making it difficult to act upon its structure for the generation of competitive advantages in the market, where the psycho-social construct of healthy organization is established as an emergency.

Objective: To offer an alternative solution to the theoretical divergence of building positive organizations.

Methodology: Development of a healthy organizational model, cellular type, based on a set of variables in which the GPTW and HERO models coincide, with the implementation of this structure, through a transit methodology that makes the objective of being the best place to work tangible.

Conclusion: Establishing a healthy organizational model of cellular structure allows for the perception of the organizational context through traceable and flexible variables that respond to internal and external labor changes.

Originality: The advances in relation to the psycho-social construct of the health organizations are limited due to multiple heterogeneous models, however, a homogeneous model is traced for the first time in this work, based on others that have been implemented in different entities.

Limitations: Establish an evaluation of the model to accurately adjust the relationship between variables.

Keywords: Healthy organizational model, transit methodology, cellular organization, HERO, GPTW.

\section{Resumen}

Introducción: Este artículo es producto de la investigación Salud y Bienestar Psicosocial en las Organizaciones: Eficacia de las intervenciones positivas para mejorar la vida laboral desde la Psicología Positiva realizadas durante los años 2016 y 2018 en la Universitat Jaume I de España.

Problema: Las condiciones cambiantes de los ecosistemas en los que se encuentran inmersas las organizaciones corresponden a las crecientes relaciones entre los diferentes actores dentro y fuera del contexto organizacional, constituyendo así sistemas complejos de difícil comprensión en el contexto empresarial, dificultando la actuación de su estructura para la generación de ventajas competitivas en el mercado, donde se establece como emergencia la construcción psicosocial de una organización sana.

Objetivo: Ofrecer una solución alternativa a la divergencia teórica para construir organizaciones positivas.

Metodología: desarrollo de un modelo organizativo sano, de tipo celular, basado en un conjunto de variables en las que coinciden los modelos GPTW y HERO. Con la implementación de esta estructura, a través de una metodología de tránsito que hace tangible el objetivo de ser el mejor lugar para trabajar.

Conclusión: Establecer un modelo organizacional saludable de estructura celular permite percibir el contexto organizacional a través de variables trazables y flexibles que responden a los cambios laborales internos y externos.

Originalidad: Los avances en relación a la construcción psicosocial de las organizaciones de salud están limitados por múltiples modelos heterogéneos, sin embargo, por primera vez se traza un modelo homogéneo basado en otros que han sido implementados en diferentes entidades.

Limitaciones: Establecer una evaluación del modelo para ajustar con precisión la relación entre las variables.

Palabras clave: Modelo organizacional saludable, metodología de tránsito, organización celular, HERO, GPTW. 


\section{Resumo}

Introdução: este artigo é um produto da pesquisa Saúde e bem-estar psicossocial nas organizações: efetividade de intervenções positivas para melhorar a vida profissional da psicologia positiva realizada durante 2016 e 2018 na Universitat Jaume I, na Espanha.

Problema: As mudanças nas condições dos ecossistemas em que as organizações estão imersas correspondem às crescentes relações entre os diferentes atores dentro e fora do contexto organizacional, constituindo assim sistemas complexos difíceis de entender no contexto empresarial, dificultando a atuação de sua estrutura. a geração de vantagens competitivas no mercado, onde o construto psicossocial da organização saudável é estabelecido como uma emergência.

Objetivo: Oferecer uma solução alternativa à divergência teórica para construir organizações positivas.

Metodologia: desenvolvimento de um modelo organizacional saudável, tipo celular, baseado em um conjunto de variáveis em que os modelos GPTW e HERO coincidem. Com a implementação dessa estrutura, através de uma metodologia de trânsito que torna tangível o objetivo de ser o melhor local para trabalhar.

Conclusão: Estabelecer um modelo organizacional saudável da estrutura celular permite perceber o contexto organizacional através de variáveis rastreáveis e flexíveis que respondem a mudanças internas e externas do trabalho.

Originalidade: Os avanços em relação ao construto psicossocial das organizações de saúde são limitados devido a múltiplos modelos heterogêneos, no entanto, pela primeira vez, um modelo homogêneo é traçado com base em outros que foram implementados em diferentes entidades.

Limitações: estabeleça uma avaliação do modelo para ajustar com precisão o relacionamento entre variáveis.

Palavras-chave: modelo organizacional saudável, metodologia de trânsito, organização celular, HERO, GPTW

\section{INTRODUCTION}

Different events in history have demanded responses that today are expressed in contributions to the development and evolution of humanity in various fields: economic, political, social, cultural, technological, among others.

The organizational sphere has not been oblivious to this change. Business organizations have created conceptual models of organizational reality, which correspond to transformations that have limited, characterized and structured their forms and strategies from the socio-labor dynamics [1], and has turned them into challenges for further academic developments, relating to the understanding and interpretation of this type of institution. [2]

The dominant traditional paradigm for the compression of organizations, characterized by its linear and reductionist nature, has become insufficient in the face of the complexity of relations inside and outside them, since the slowness, inflexibility and fragility of this model are the constant in decision-making [3]. 
An alternative, to overcome these difficulties, is complexity as a new paradigm model of apprehension of organizations, which, based on the postulates of the sciences of complexity, conceives organizations as complex systems [3].

In recent times the fundamental issue in the transformation of organizations has been the promotion of health as the ultimate goal of conception. The World Health Organization (WHO) defines it as a "state of complete physical, mental and social well-being, and not merely the absence of disease or infirmity [4] ". This establishes a differential with regard to the coherence of relations between organizations, components and sustainable development with the environment. [5]

The emerging reality implies the appearance of models that lead to a divergent reading of unknown patterns, so that it confronts the internal socio-labor practices to reach a definition of its own that fosters the dynamics of organizational change.

In order to understand and act in this new reality, it is necessary to establish healthy organizational models that face the complexity of both the environment and the organizations themselves.

In this context, "healthy organizations are those that carry out systematic, planned and proactive actions to improve the processes and outcomes of both employees and organizations as a whole [6] ".

It should be noted that there are several factors that complicate the implementation of healthy organizational models. One of these factors is the lack of a relevant number of investigations that comprehensively test the theoretical schemes, and not only partial aspects of them. Progress in this area is limited, which exposes multiple organizational models with a heterogeneity of variables. This study therefore proposes not only to provide a model based on the articulation of other theorists/practitioners such as the Healthy \& Resilient Organization (HERO) and Great Place to Work (GPTW) models, but also to establish a base methodology to achieve the objective of being the best place to work in a healthy organizational context.

\section{ORGANIZATIONAL PERSPECTIVES OVER TIME}

Market dynamics are framed by accelerated change. Organizational systems develop in synchrony with social transformation processes, and this evolution is framed by the elements that make up each organization: people, resources, finances, etc. [7].

In this sense, it is necessary to mention that there are several actors and elements that interpret and develop change within organizations. The theory of human 
relations proposes that it is the members of each company who decide what function they perform and how they carry it out, promoting a behavior linked to self-realization [8]. That is why the statement "the more satisfied you are with your organization, the more willing you are to work for it [9]" exists.

In consideration of Gary Kreps and his work on organizational design systems and frames of reference, it is necessary to assume the dynamics that contribute to each moment of organizational history [10].

The first of these systems focuses on the approach to decent work, where the organization responds to the worker's vision as a resource to be exploited, limited for the tasks of planning and decision making. This dynamic is characterized by a high degree of control and authority, as a response to the first hierarchies of Maslow's Pyramid, physiological, which focuses its efforts on aspects of safety and hygiene, related to health, rather than health itself [8].

The second system consists of an approach to the current concept of organization from the resources and capacities, where the main perspective is to see the worker as a resource to cultivate that contributes little to the decisions of the organizations, but to whom the directors allows them to externalize their complaints and opinions. It is an organization that, according to the Maslow Pyramids, has a coordination mode based on the social normalization of results. In the field of prevention, perspectives linked to the ergonomics of the post and the systems are beginning to be circumscribed [11].

The third, establishes an approach from the social responsibility of the company, by raising two different perspectives of the worker; one as an internal client with certain needs to consider and another as a member of the external community, the ecosystem where the organization is immersed. In both cases, the organization encourages communication between the different hierarchical levels, which restricts confidence in the decision-making capacity of workers [12]. At the prevention level, certain work conditions are considered, related to low levels of participation, autonomy and responsibility, which introduces psychosociology from a negative perspective, that is, organizational health as a means and not as an end [13].

The fourth and most recent system sees the organization proposing an integral approach to the collaborator from the mission and presenting them as a human being with whom the organization develops mutually. To a certain degree, the direction of the organization depends on the worker's feedback and ideas. In this type of organization, promotion is "proactive and considers not only the risks but also the development factors of the worker [12] ". 


\section{HEALTH AT THE ORGANIZATIONAL LEVEL}

The essential thing is the maximum development of health in society and of the actors that are found in the organizations. It is through structures that the health of human beings in the social and labor scope is made possible.

During the first half of the twentieth century, thanks to the hygienic approach of disinfection and sterilization for health, improvements were observed in labor conditions. After the 1950s, a whole quality of working life movement unfolds that involves the development and adoption of practices ranging from industrial safety, quality and productivity to the implementation of sound environmental practices [14]. However, these theoretical-practical efforts for health at the organizational level are mostly oriented exclusively towards the economic benefit of the organizations [1], that is, they consider health as a cost or at most an investment.

Because of the foregoing, in organizational contexts, the approach to health has required overcoming the negative bias of health care. In this instance, the importance of a positive approach to health, in organizations focused on the strengths and optimal behavior of people in organizations, is recognized [15]. In this way, Positive Organizational Psychology (POP) is developed, which responds to the understanding of the concept of integral health applied to the workplace [16].

Understanding the concept of organizational health from a holistic perspective recognizes two perspectives: organizational health (negative perspective) and health in the organization (positive perspective) (See Table 1.) [1]. 
TABLE I. DIFFERENCES BETWEEN ORGANIZATIONAL HEALTH PERSPECTIVE AND PERSPECTIVE HEALTH IN THE ORGANIZATION . [1]

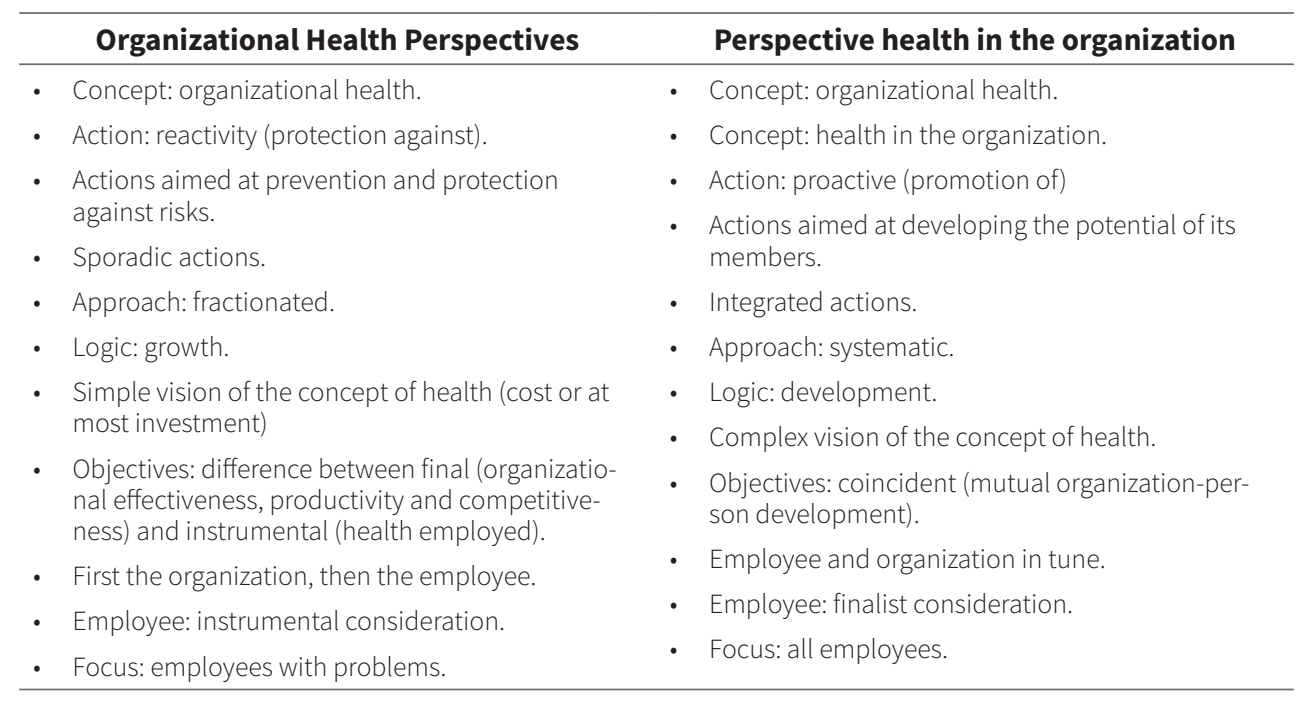

Source: own work

\section{HEALTHY ORGANISATIONAL CONTEXTL}

Positive Organizational Psychology (POP) is the discipline responsible for applying psychology to improve the quality of working life, and to protect and promote the safety, health, and well-being of workers [17]. The POP tries to promote the development of organizations committed to health promotion, positive organizations [16].

Positive organizations are those that seek organizational excellence and financial success through psychologically healthy and motivated employees, capable of maintaining a positive organizational culture, particularly during periods of intense change and turbulence and change [18].

In this context, healthy and resilient organizations or HEROs are born; those that "carry out systematic, planned and proactive actions to improve the processes and results of both employees and the organization. In addition, they are resilient because they manifest a positive fit under challenging circumstances [6] ".

HERO is a heuristic model of healthy organizations that responds to the limitations of the systematic first step to understanding how organizational practices relate to employee health, conducted by [19]. This model limited its scope to the use of strictly individual validation methodologies, even though the assumption of a healthy organization implies a collective evaluation. [20]. 


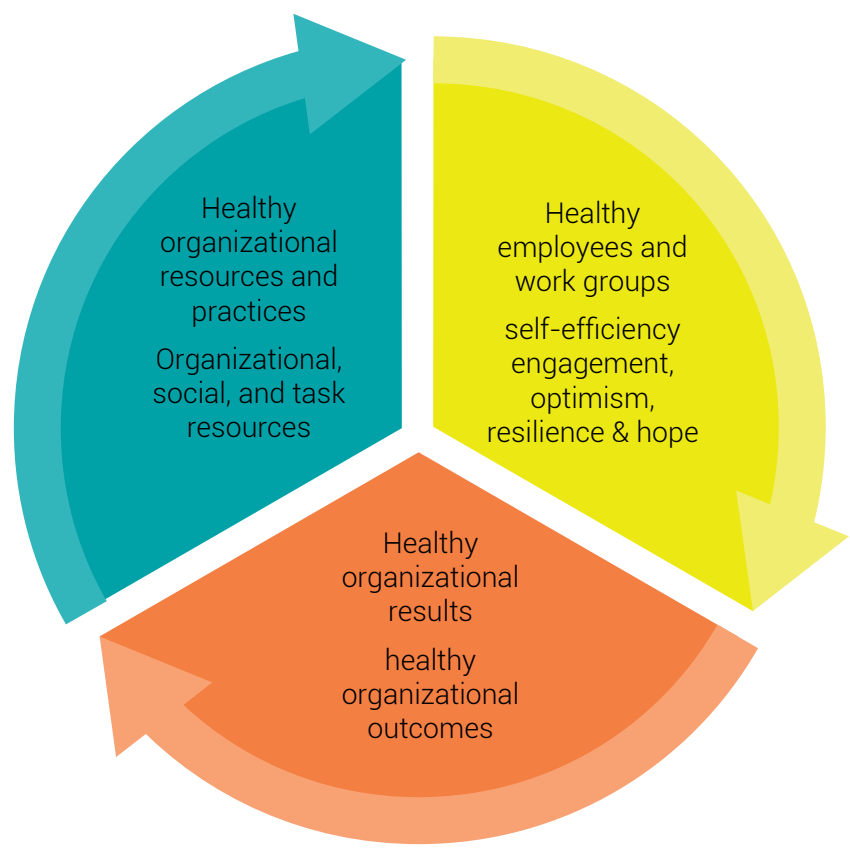

Figure 1. Healthy \&amp; Resilient Organizations Model Source: [21]

The HERO model integrates empirical and theoretical results at multiple levels of analysis (individuals, groups and organizations) [20], on the positive relationships of the three components from which it is made: healthy organizational resources and practices, healthy employees and work groups, and healthy organizational results [22] (see Figure 1).

The psychosocial construct of healthy organizations has been approached from different approaches. The constant in recent years has been the multiplicity in organizational models that develop the concept.

For example: In relation to the Global Plan of Action on Occupational Health 2008-2017, a product of the 60th World Health Assembly [23], WHO builds the Global Framework for Healthy Workplaces, and defines healthy organizations as those where "workers and managers collaborate in a process of continuous improvement to protect and promote the health, safety and well-being of all workers, as well as the sustainability of the workplace [24]".

The WHO model is composed of four dimensions: physical work environment, psychosocial work environment, participation of the company in the community, and personal and health resources, on which continuous improvement actions are carried out in order to preserve and promote health, reduce the possibility of occupational 
risks and ensure great well-being for all, always based on the ethical commitment of each of the members [25].

On the other hand, Canada's national authority on Healthy Work and Quality practices, Excellence Canada, known before 2011 as the National Quality Institute (NQI), has built a unique model in terms of measurable standards and validation [26]. Its objective is the excellence of organizations in health, as well as the well-being and productivity of all those with whom it interacts [25].

This model of healthy organization contemplates four principles: leadership, planning and program, processes and risk management, as well as the commitments of people, which, through the fulfillment of four other elements: the physical environment, a healthy lifestyle, mental health and professional culture, and corporate responsibility [27], allow all agents who interact with the organization to be healthy, in the configuration of a healthy environment in the organization [25].

From another perspective, the Integral Model of Healthy Organization (MIOS) is presented, under which this type of organization is defined "as those that enjoy a state of well-being in function of their relational and structural factors, both internal and external [28]".

MIOS bases its development on the systematic study of two types of factor; relational and structural. The first seeks to analyze the quality and quantity of interactions within and outside the organization, and the second analyzes the promotion of these relationships according to the resources and structure of the organization [28].

\section{GREAT PLACE TO WORK MODEL}

Throughout the years GPTW has consolidated a model that identifies, creates and maintains cultures of high performance, as a result of the practice of habits based on trust, camaraderie and pride within the organizations. This consulting firm has been working for over 30 years to make companies the best places to work. In order to achieve this goal, the largest survey of employees worldwide is carried out every year using instruments such as Trust Index (c) and Culture Audit (c) [29].

The Trust Index @ tool measures the value employees give to the organization as a workplace in terms of five dimensions based on universal values (see Figure 2 (a)): credibility (how the employee perceives leaders and the organization); respect (how the employee thinks he is seen by his superiors); impartiality (absence of discrimination, clear rules, making decisions in a timely manner); pride (image of the company in society) and companionship (feeling of family and team) [30]. 
The Culture Audit@ tool documents human capital practices, processes, policies and initiatives through 15 steps or cultural competencies (see Figure 2 (b)).

The HERO and GPTW models are exceptional insofar as they have tested their theoretical advances through practice and strategies and variables linked to an accurate approach to the concept of healthy organizations. Therefore, the structuring of an organizational model is transcendent if it is constructed from valid and consolidated information that overcomes the heterogeneity restrictions of the construct. However, there is a need to involve other methodologies to guide the transition from traditional to healthy organizations. In this way, this document not only seeks to present an organizational model of the best places to work in a healthy context, but also to expose a methodology that serves as a basis for transit [31].

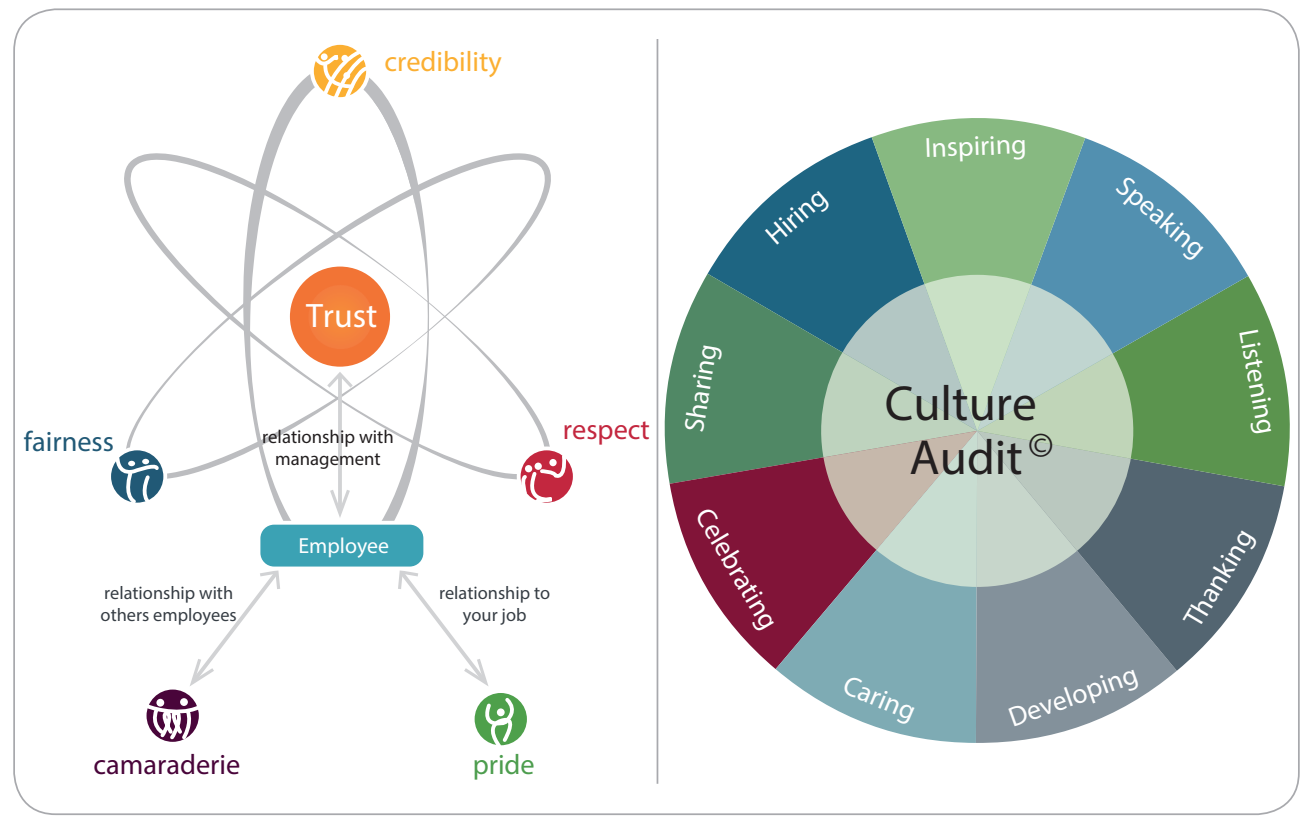

(a)

(b)

Figure 2. (a) Model $\odot$ Great Place to Work ${ }^{\circledR}$ Trust Index $\odot$

(b) Model @ Great Place to Work ${ }^{\circledR}$ Culture Audit@

Source: [30] 


\section{HEALTH FROM THE ORGANIZATIONAL LEVEL}

The HERO model raises those organizations that optimize their resources and develop healthy organizational practices, give rise to healthy employees and work teams, resulting in the promotion of healthy organizational results [6].

The first basic element of the HERO model is made up of resources and healthy organizational practices. It has three types of resources that interact with each other in a coordinated manner to positively influence work results[32]: organizational, social, and task resources [33].

Resources are defined as those units of value ascribed to individuals that enable them to achieve objectives [34]. The POP, based on the Conservation of Resources (COR) Theory, establishes that in the organizational context, resource management seeks to promote the health and psychosocial well-being of employees [15].

Organizational resources are those that foster collective well-being by strengthening relationships between employees and the organization, creating feelings of pride, belonging, loyalty and organizational commitment. [21].

One of the organizational resources that in recent times has generated great academic and practical research interest is transformational leadership [18]. This type of leadership is defined as one that rethinks situations and provides a creative vision to promote higher levels of creativity among subordinates [35].

The organizational culture variable is defined as the set of shared values, "beliefs or perceptions that employees have within an organization or organizational unit [36]", and is also distinguished for being the one with the greatest influence on the interactions of the elements of organizations, understood as systems [37].

Another relevant concept is professional development, which refers to employees "perceptions of their employment possibilities in the internal and/or external work market [38]". This configures in function of a norm of reciprocity between the organization and the individuals or work groups, according to the resources invested by them.

For its part, perceived organizational support is conceived as employees "beliefs about the extent to which the organization values their contribution and cares for their well-being [39]".

The social resources of the HERO model promote the interpersonal relationships of employees and groups at work in the organizational context. These multilevel interpersonal relationships encompass both the relationships with the people you work for, for whom you work, and over whom you supervise work [21]. 
Organizational trust becomes the necessary social resource of the positive relationships of business institutions. Its definition is possible depending on the orientation of the exercise: " (a) Vertical trust, considered as the degree to which employees trust the actions of their superiors or the organization in which they work; (b) Horizontal trust, considered as the degree to which employees trust the people with whom they work, trust what they do and enjoy them [18]".

The task resources of the HERO model are those that are close to the work of the employee in the organization. Some of the most commonly used task resources in organizations are: clarity of tasks and job role, feedback for what is done, autonomy, communication channels, job design and redesign [21].

Feedback is the "exercise of focusing the attention of team members on their role and responsibilities, informing people when their behavior moves away from the team's goal, and promoting learning from past performance episodes [40]".

The second basic element of the HERO model is related to healthy employees recognized as the psychological mechanism through which healthy organizations achieve positive results [22].

In relation to the COR, the resources related to the psychological well-being of employees at work are nothing more than the combination of personal resources, such as hope (ability to assume the best persevering position on the objectives), effectiveness (competence to trust is their own skills), resilience (ability to overcome obstacles) and optimism (positive state facing the future), among others [41].

The psychological capital of healthy employees and work groups in the organization is maintained and amplified through two variables: self-sufficiency and engagement [21].

Self-sufficiency is the accumulation of "beliefs in one's own capacities to organize and execute the required courses of action that will produce certain achievements or results [21]".

For its part in the workplace, engagement responds to "the affective state of fullness characterized by vigor, dedication and absorption or concentration at work. The vigor, represents the high levels of energy and mental activation in the work, the willingness to invest efforts and persistence, in the face of difficulties [21]".

Finally, the third element of the HERO model comprises healthy organizational outcomes that represent satisfaction by stakeholders (suppliers, customers, financial institutions, state institutions, civil society, etc. ) [3]. Some of these results are improved performance, quality of work, productivity and corporate social responsibility. 


\section{TO THE BEST PLACES TO WORK}

The GPTW Institute has developed and validated worldwide a model for understanding healthy work environments based on three variables: trust, camaraderie and pride.

Trust is related to what inspires leaders and the company, to the camaraderie that is present in the group, and to the pride produced by work, the team and the company.

Organizational trust inspires different reflections that come from the operating processes of each organization, starting from the fact that organizations seek to ensure the cooperation of the different actors within it. [42].

Therefore, "trust is a fundamental part of an organization's efficiency and performance [42]." Furthermore, it is a critical factor insofar as cooperation is affected and even leadership effectiveness is reduced or negligible if there is the absence of this variable, given that communication is restricted and motivation is diminished [43].

Authors such as Mehrabi establish that trust comes from the continuous monitoring of codes of ethics, so the socialization and communication of these documents is a relevant action for the creation and development of trust in multidimensional contexts, so it is necessary to prioritize these values in the work environment.

GPTW distinguishes three variables that affect organizational trust: credibility, respect and impartiality. Factors such as information, accessibility, coordination, delegation, vision, reliability and honesty all play a role in credibility. Respect involves development, recognition, participation, as such, the work environment and personal life. Finally, impartiality establishes its relationship with equity in remuneration, treatment, absence of favoritism, justice in the treatment of persons and the ability to appeal.

In short, trust is defined as the willingness of employees to be vulnerable to the actions of their organization, without meaning that they exercise control over these actions and behaviors, but through the development of relationships based on respect and impartiality which helps identify the perception of the employee towards his superiors and the company [44].

Communication is used to share experiences and knowledge. The communication process takes place through conversational skills and discourses, which allow for the formation of interconnected networks that unite and strengthen the system. Effective communication is based above all on personal, close and direct contact between people. The main function of this communication system is none other than to create a shared company, which guarantees the participation of the whole group in the emission, reception and comprehension of messages adapted to the jargon of the addressee. 
Communication is important in organizational systems, so when studying the organizational climate, it is important to explore, in addition to the traditional leadership, motivation, remuneration and participation, the inclusion of communication as another dimension to be studied [8]. In short, "organizational communication is the total set of messages that are exchanged among the members of an organization, and between the organization itself and its environment [10]."

On the other hand, camaraderie offers the individual the possibility of being and becoming part of an ideally pleasant and open social environment with a sense of family or team. "One of the bases of fraternity as the axis of camaraderie, is to belong to some group, association, etc. to have someone and to cooperate among others [45]."

The willingness of workers and productivity are factors associated with camaraderie, because when cultivating this pillar in any organization, each actor seeks to give the best of himself and makes extra efforts to achieve better results. In this sense camaraderie is defined as the experience of the individual in front of a working team characterized by fraternity, hospitality of both the place and the person, and a sense of team oriented cooperation [30].

Teamwork can be defined as a small number of people with complementary skills, who are committed to a purpose, a set of performance goals and a common approach, for which they hold each other accountable [46].

Synergy is part of the integration of work teams and is understood as the ability of the company to generate more economic value than each strategic business unit would produce independently. In turn, it is defined as the process where the action of two or more causes produces together an effect of greater magnitude or quality than would be achieved by acting separately.

Of the various key factors within the provision of leadership and teamwork, integrity is a fundamental part of any development within or outside the organization, as it fosters the development of trust and increases commitment [47].

Integrity is the level of acceptance of the correspondence between the values expressed through words and what is shown in action [48].

Pride is one of the pillars most perceived by employees [30]. It means being honored for the work. It is possible to evaluate the individual, that is to say, to analyze how flattered the collaborator feels for the contribution of his actions to the objectives of the organization; to the team, to evaluate how proud the collaborators are for the joint effort and the achievements; and the company, implies to give relevance to the opinion that the employees have on the company and on its reputation in the community [30]. 
In short, pride is the level of value of the collaborator towards the work and the image of the company in the community.

\section{CELLULAR TYPE HEALTHY ORGANIZATIONAL MODEL}

\section{a. CELLULAR ORGANIZATION}

Organizational structures have evolved from the hierarchical, through to the matrix, the network and even cellular forms. The latter consists of units (self-managed teams, autonomous business units, etc.) that operate on their own, but interact with other units to produce a more powerful and competent business mechanism.

This type of structure is based on acting on the continuous process of innovation, in such a way that each unit has an entrepreneurial responsibility within the organization. The cellular organization goes from creating and sharing knowledge to taking advantage of all the assets of that knowledge.

\section{b. CELLULAR TYPE HEALTHY ORGANIZATION MODEL}

Based on the literature in previous sections, a healthy cellular-type organizational model is established, which seeks to contrast with current hierarchical systems. This model allows the constant evolution of the organization, by establishing fundamental elements that give meaning to the whole set of interactions between the different organizational actors and their environment.

The cellular-type organizational model is characterized by establishing a horizontal and participatory organizational system, which generates a shared vision based on reality, allowing effective decision-making as it responds to present situations.

This structure is composed of key variables within the organizational dynamic that considers the collaborator and the work teams as the main focuses within communication and trust promotion.

The healthy cellular type organizational model requires an organizational system composed of the following variables:

- Organizational Culture: collection of milestones, myths, rites and beliefs of the organizational collective.

- The concept of development: a set of practices for the social exchange of work (resources) between employees, work teams and the organization for the benefit of the skills required by the working environment [38]. 
- Professional support: consideration, assessment and promotion of the work of employees or the working group within and outside an organization.

- Recognition: humanistic distinction of the individual or group of individuals behind the labor role within an organization [49].

- Teamwork: a group of people committed to one or more common purposes characterized by fraternity, a sense of teamwork and hospitality.

- Synergy: working together between two or more actors towards a coordinated achievement.

- Integrity: level of acceptance of a correspondence between the values expressed through the words and what is shown in the action [48].

- Communication: set of interactions of all kinds between the different actors of the organization and the ecosystem where it is immersed.

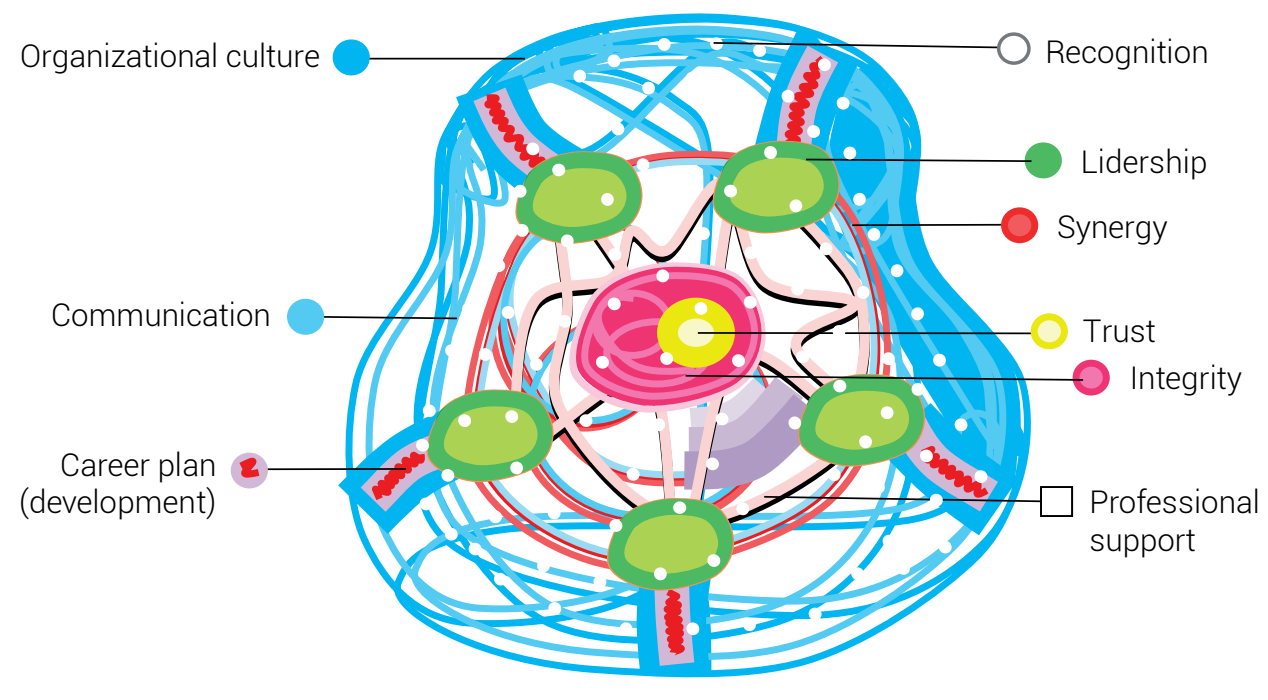

Figure 3. Healthy cellular-type organizational model.

Source: own work

\section{METHODOLOGY OF TRANSITION TO CHANGE}

For an effective transition from traditional to healthy organizational models, the different manifestations at the symbolic, social, and political levels that legitimize the actions of members within the organization must be considered [50]. 
The transit methodology must be aligned with the company's organizational reality, supported by efficient change management planning and obtaining accurate information to validate the real state of the organization in the different stages of this process. This ensures that we act in accordance with the evolution of the model [51].

The proposed methodology is built from the PDCA cycle, as a strategy for adoption and obtaining a new organizational model based on the need for change.

\section{Plan}

Diagnosis of the organizational reality: At this stage of the process it is necessary to evaluate and know the reality of the organization before creating changes. This is achieved by determining the level of experience, planning, and participation needed for change to be successful, and the desired degree of transformation [43].

Linking actors to change: In order to achieve an effective transition to a healthy organizational model, it is necessary to identify the leaders who will lead the change process through transparency and openness, by creating effective methods that make sense of change for all actors in the organization [52].

\section{Do}

Integration with change: Human beings act under incentives; therefore, it is necessary to establish relevant reasons justifying the reasons for being change managers. It is important to involve and engage stakeholders, ensure critical activities within the process, and keep in mind that the way change is made is as important as what is being changed [43].

Change-culture alignment: Within the transit the desired changes must be aligned with the strategy and culture of the organization, considering the foreseen and unplanned consequences of this process. The momentum must be persistent and each step must be taken with a positive and proactive approach [43].

\section{Check}

Change performance: Constant measurement of the change process suggests reliable feedback mechanisms with which early action can be taken to facilitate adjustment of the action plan. A key factor is communication, as reporting progress and acknowledging successes allows for ownership of the process and creates an emotional bond associated with inclusion and participation. It is necessary to take 
into account all those involved by listening to the opinions of those who agree and those who disagree [43].

Valuation of the change process: For a correct valuation it is necessary to orient the results to change objectives. This is achieved by investing the necessary time in a correct measurement, without forgetting that this must be fully aligned with the desired change [43].

\section{Act}

Continuous improvement: The organization must ensure constant learning of the process of change. In order to achieve this, it is necessary to resort to what has been learned or include variables that have a greater impact and relevance in the organization [43].

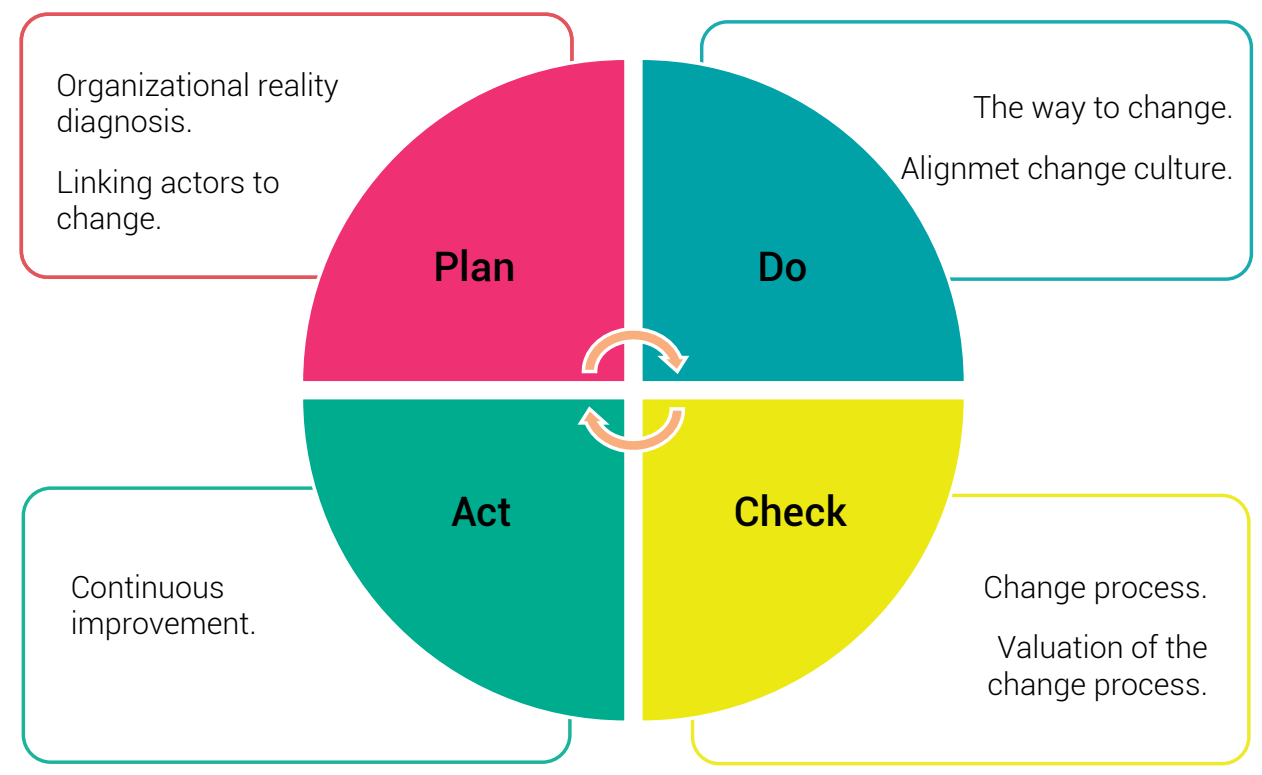

Figure 4. PDCA / PDSA cycle. Transit methodology.

Source: own work

\section{CONCLUSIONS}

Organizational structures, understood as a competitive advantage, have been underestimated over time, however, the dynamics linked to work and personal development inside and outside organizations, and the generation of increasingly complex 
relationships, represents an opportunity for change that is achieved through the implementation of healthy organizational models that allow flexible structures, continuous improvement and management through self-directed multidisciplinary teams that generate a rapid response to change.

As stated throughout the article, the healthy cellular organizational model is a theoretical approach to the consolidation of better places to work in a dynamic organizational context, therefore, becoming an alternative solution to the problem of multiplicity and heterogeneity of the psychosocial construct that bases its relevance on the use of variables validated through the GPTW and HERO models.

The structure of this healthy organizational model is built from systemic thinking which contemplates properties of emergency, interdependence, self-management and evolution of business institutions, fruit of the interaction of the different agents of the labor context. The objective of this model is to base relationships on trust, through the establishment of criteria of culture, companionship and professional development.

The change requires the adoption of a transit methodology adjusted to each type of organization, which should give as a response a full participation of the actors who influence the change and an alignment to the culture of the organization.

It is also imperative to have mechanisms for generating accurate information, so that the action plan is not limited to the transit of an organizational structure that provides a competitive advantage over less efficient alternatives.

\section{REFERENCES}

[1] M. Á. Gimeno, A. Grandío, and A. I. Marqués, "El cambiante mundo de las organizaciones. Hacia una organización saludable," Rev. Int. Organ., pp. 41-63, 2013.

[2] M. Kriger and Y. Zhovtobryukh, "Creating Truly Healthy Organizations in the Long Term," in Strategic Leadership for Turbulent Times, New York: Palgrave Macmillan US, 2016, pp. 115-133.

[3] L. E. Bohórquez, "La comprensiín de las Organizaciones Empresariales y su Ambiente como Sistemas de Complejidad Creciente: Rasgos e Implicaciones," Ingeniería, vol. 21, no. 3, pp. 363-377, 2016.

[4] OMS, "Basic Document: Forty-eighth edition," World Health Organization. 2014.

[5] L. E. Tetrick and C. J. Winslow, "Workplace Stress Management Interventions and Health Promotion," 2015. 
[6] M. Salanova, S. Llorens, and I. M. Martínez, Organizacioens Saludalbes Una mirada desde la psicologpia positiva. 2019

[7] R. R. Sharma et al., "The Challenge of Fostering Healthy Organizations: An Empirical Study on the Role of Workplace Relational Civility in Acceptance of Change and Well-Being," Front. Psychol. | www.frontiersin.org, vol. 7, p. 1748, 2016.

[8] A. M. Segredo Pérez, "Aproximación teórica a la evolución, teorías, enfoques y características que han sustentado el desarrollo de las organizaciones," Rev. Cuba. Salud Publica, vol. 42, no. 4, pp. 585-595, 2016.

[9] O. E. Contreras and I. R. Rojas, "Teletrabajo y sostenibilidad empresarial. Una reflexión desde la gerencia del talento humano en Colombia," Suma Negocios, vol. 6, no. 13, pp. 74-83, Jan. 2015.

[10] A. M. Segredo Pérez, A. J. Garcia Milian, P. L. López Puig, P. León Cabrera, and I. Perdomo Victoria, "Comunicación organizacional como dimensión necesaria para medir el clima en las organizaciones en salud pública," Horiz. Sanit., vol. 16, no. 1, p. 28, 2017.

[11] E. L. Deci, A. H. Olafsen, and R. M. Ryan, "Self-Determination Theory in Work Organizations: The State of a Science," Annu. Rev. Organ. Psychol. Organ. Behav, vol. 4, pp. 19-43, 2017.

[12] M. Ángel, G. Navarro, A. Grandío, and A. I. Marqués, "Hacia una organización saludable," Rev. Int. Organ., pp. 41-63, 2013

[13] M. A. Carrion et al., "Preventing Psychological Wear in Healthy Organizations. Research in the State of Hidalgo, Mexico," Eur. Sci. J., vol. 12, no. 20, 2016.

[14] M. Alejandra, G. Vélez, P. Andrea, and C. Carrascal, "Salud mental en el trabajo : entre el sufrimiento en el trabajo y la organización saludable,” pp. 177-201, 2017.

[15] H. Acosta, V. Cruz-Ortiz, M. Salanova, and S. Llorens, "Organizaciones saludables: Analizando su significado desde el Modelo HERO," Rev. Psicol. Soc. / Int. J. Soc. Psychol., 2015.

[16] M. Salanova, S. Llorens, and I. M. Martínez, "Aportaciones desde la Psicología Organizacional Positiva para desarrollar organizaciones saludables y resilientes," Papeles del Psicólogo, vol. 461, no. 7268, pp. 177-184, 2016.

[17] "CDC - Acerca de NIOSH." [Online]. Available: https://www.cdc.gov/spanish/niosh/ab-sp. html. 
[18] J. Olvera, S. Llorens, H. Acosta, and M. Salanova, "El liderazgo transformacional y la confianza como antecedentes del desempeño en equipo en el ámbito sanitario," An. Psicol., vol. 33, no. 2, pp. 365-375, 2017.

[19] M. G. Wilson, D. M. Dejoy, R. J. Vandenberg, H. A. Richardson, and A. L. Mcgrath, "Work characteristics and employee health and well-being: Test of a model of healthy work organization," J. Occup. Organ. Psychol., vol. 77, no. 4, pp. 565-588, Dec. 2004.

[20] M. Salanova, S. Llorens, E. Cifre, and I. M. Martínez, "We Need a Hero! Toward a Validation of the Healthy and Resilient Organization (HERO) Model," Gr. Organ. Manag., vol. 37, no. 6, pp. 785-822, 2012.

[21] M. Salanova, "Organizaciones saludables, organizaciones resilientes," Gestión Práctica Riesgos La-borales, pp. 18-23, 2009.

[22] S. D. T. Martins and N. Silva, Psicología positiva en las organizacionesy en el trabajo. Conceptos fundamentales y significados aplicados. 2017.

[23] World Health Organization (WHO), "Workers' health: global plan of action," Sixtieth World Heal. Assem., no. May, pp. 1-8, 2007.

[24] OMS and OPS, "Ambientes de Trabajo Saludables: un modelo para la acción. Para empleadores, trabajadores, autoridades normativas y profesionales," Rev. biomecánica, vol. 45, no. 3, pp. 1-26, 2013.

[25] T. Jacob and G. Reinders, "Healthy Organizations Ae1049 - Final Degree Project Academic Year 2017-18." 2017.

[26] "About Us - Excellence Canada." [Online]. Available: https://excellence.ca/about-us/

[27] "Healthy Workplace - Excellence Canada." [Online]. Available: https://excellence.ca/ healthy-workplace-standard/

[28] M. P. Grueso-Hinestroza and C. F. Rey-Sarmiento, "Hacia la construcción de un Modelo Integral de Organizaciones Saludables Toward the Construction of an Integral Model for Healthy Organizations," Rev. Ciencias Soc., vol. XIX, no. 4, pp. 625-638, 2013.

[29] B. Scholz, P. Research Fellow Julia Bocking, B. Happell, P. of Nursing, and E. Director, "How do consumer leaders co-create value in mental health organisations? Health Service Research," J. Compil. Ó AHHA 2017 Open Access CC BY-NC-ND Aust. Heal. Rev., vol. 41, pp. 505-510, 2017. 
[30] R. Centroam, Los Mejores Lugares Para Trabajar, p. 28, 2018.

[31] O. I. Vásquez-Rivera, "Cultural analysis in three indigenous productive organizations from an interpretive-symbolic perspective," Cuad. Adm., vol. 33, no. 0120-4645, 2017.

[32] S. Tafvelin, K. Nielsen, U. von Thiele Schwarz, and A. Stenling, "Leading well is a matter of resources: Leader vigour and peer support augments the relationship between transformational leadership and burnout," Work Stress, vol. 33, no. 2, pp. 156-172, 2019.

[33] I. Sanchez C., "Learning to be a hero: linking organizational learning practices to healthy and resilience organizational outcomes.," Strateg. Leadersh., vol. 44, no. 4, pp. 3-9, 2017.

[34] M. D. Merino, J. Privado, and R. Arnaiz, "Is There Any Relationship between Unemployment in Young Graduates and," J. Work Organ. Psychol., vol. 34, no. 1, pp. 1-8, 2019.

[35] A. Di Fabio and J. M. Peiró, "Human capital sustainability leadership to promote sustainable development and healthy organizations: A new scale," Sustain., vol. 10, no. 7, 2018.

[36] W. C. Taylor, R. R. Suminski, B. M. Das, R. J. Paxton, and D. W. Craig, "Organizational Culture and Implications for Workplace Interventions to Reduce Sitting Time Among Office-Based Workers: A Systematic Review," Front. Public Heal., vol. 6, no. September, 2018.

[37] H. R. Espacios and L. O. S. Cultura organizacional, retos y desafíos para las organizaciones saludables, 2018.

[38] J. Akkermans, M. Tims, S. Beijer, and N. De Cuyper, "Should employers invest in employability? Examining employability as a mediator in the HRM - commitment relationship," Front. Psychol., vol. 10, no. APR, pp. 1-10, 2019.

[39] G. Giorgi, D. Dubin, and J. F. Perez, "Perceived organizational support for enhancing welfare at work: A regression tree model," Front. Psychol., vol. 7, no. DEC, pp. 1-9, 2016.

[40] E. Glikson, A. W. Woolley, P. Gupta, and Y. J. Kim, "Visualized automatic feedback in virtual teams," Front. Psychol., vol. 10, no. MAR, pp. 1-11, 2019.

[41] M. Carmona-Halty, W. B. Schaufeli, and M. Salanova, "Good relationships, good performance: The mediating role of psychological capital - A three-wave study among students," Front. Psychol., vol. 10, no. FEB, pp. 1-5, 2019. 
[42] O. M. M. M. De Lima Rua and J. M. Costa Araújo, "Relacionando liderazgo transformacional y confianza organizacional: ¿Tiene el compromiso organizacional un efecto mediador?," Cuad. Gest., vol. 16, no. 1, pp. 43-62, 2016.

[43] D. D. Warrick, "The Urgent Need to Educate Present and Future Leaders in Organization Development and Change.," OD Pract., vol. 49, no. 3, pp. 52-58, 2017.

[44] F. Sanabria, La Confianza Organizacional Como Variable Mediadora Entre El Capital Psicológico Y La Conducta De Compartir Conocimiento, 2017.

[45] R. P. Uribe, Correlation Between Top Management Credibilityand Camaraderie With the Formation of an Atmosphere of Respect in the, 2013.

[46] J. Katzenbach and D. Smith, "La disciplina de los equipos," Harv. Bus. Rev., vol. 89, no. 11, pp. 118-128, 2011.

[47] A. Di Fabio, L. Palazzeschi, and O. Bucci, "Gratitude in Organizations: A Contribution for Healthy Organizational Contexts," Front. Psychol., vol. 8, p. 2025, Nov. 2017.

[48] A. Gea, "Personal Integrity and Leadership," Humaniora, vol. 7, no. 3, p. 359, 2016.

[49] K. M. Sutcliffe, T. J. Vogus, E. Dane, and J. H. Jones, Mindfulness in Organizations: A Cross-Level Review, 2016.

[50] J. M. Herrera Caballero and D. Bernal Domínguez, "Sobre la transferencia de modelos organizacionales. (Spanish)," Transf. Organ. Model., vol. 23, no. 2, pp. 331-357, 2014.

[51] N. S. Aibaghi Esfahani, Saeed; Rezaii, Hamid; Koochmeshki and S. Parsa, "Sustainability and human resource management: reasoning and applications on corporate websites," Eur. J. Int. Manag., vol. 3, no. 4, pp. 419-438, 2009.

[52] J. N. N. Ugoani, Kics: A Model of Motivational Leadership In Organizations, vol. 6, no. 3. Instituto Federal de Educação, Ciência e Tecnologia de São Paulo, 2015. 